\title{
Beyond reconciliation - Monistic Yahwism and the Problem of Evil in philosophy of religion
}

J W Gericke ${ }^{1}$

(University of Pretoria)

I want everything explained to me. And reason is impotent when it hears this cry from the heart. The mind aroused by this insistence seeks and finds nothing but contradictions and nonsense. The world itself, whose single meaning I do not understand, is a vast irrational.

Albert Camus

\section{ABSTRACT \\ Beyond reconciliation - Monistic Yahwism and the Problem of Evil in philosophy of religion}

Reconciliation is a central concern in the religious discourse of biblical Yahwism. However, one frequently overlooked part of the equation for reconcilement is the insistence in many Old Testament texts that YHWH is ultimately the necessary cause of metaphysical, natural and moral evil in the world. In this article, the author aims to demonstrate why any biblical theology of reconciliation will be problematic, given the inextricable presence of a monistic ontology underlying the relation between YHWH and evil in many biblical texts. Taken seriously, these trajectories in Old Testament Yahwism deconstruct the so-called 'Problem of Evil' along with virtually every popular theodicy constructed in the philosophy of religion.

\section{INTRODUCTION}

In Old Testament religion, the subject of reconciliation is a central issue (cf Eichrodt 1967:11). It is clear from even a cursory reading of the texts that much of the religious life of the people of the Bible is concerned with either the restoration or the maintenance of reconcilement with the divine, with other people and with the world they live in. In all this, it is commonly taken for granted that their god, YHWH,

1 This article was written as part of a post-doctoral fellowship at the Department of Old Testament Studies at the University of Pretoria. 
plays a central role in initiating and maintaining the process (Fretheim 1984:1). However, any biblical view on reconciliation becomes complicated, and indeed problematic, when one considers what is known in philosophy of religion as the 'Problem of Evil' and in biblical theology as 'theodicy' (cf Crenshaw 1990; Hick 1968). According to Hick (1990:21), the Problem of Evil in its classical form can be articulated as follows:

1) God is omnipotent

2) God is omnibenevolent

3) Evil exists.

If God is omnipotent, surely he must be able to prevent evil from occurring. If he is omnibenevolent, he will want to prevent evil from occurring. And if he is thus both able and willing to prevent evil, why does it exist? Unless then one intends to deny that there is such a thing as evil, one must either deny that there is a God or, if this is unacceptable, deny that the divine is either omnipotent or omnibenevolent (or both). But since traditional orthodox Judaeo-Christian theology would want to assert all three premises, the Problem of Evil presents a genuine philosophical and logical puzzle.

Of course, many types of theodicy (justifications of God) have been produced. These include, for example, the 'free-will' theodicy, the 'best-of-all-possible-worlds theodicy' and the 'soul-making' theodicy. These three attempted solutions to the Problem of Evil have in common the desire to leave all three premises of the problem unchallenged while each in their own way insists that even an omnipotent and omnibenevolent God will not want to prevent evil in a world designed for humans as free autonomous agents who need to grow spiritually in order to exist in a genuine relationship to the divine (cf Platinga 1974:4; Hick 1968:9).

One also encounters what is called the 'process' theodicy, favoured by process theists, who insist that the problem as it stands is insoluble and that the premise that needs be discarded is the one based on the assumption that God is omnipotent. In this case, people would rather worship a loving but sometimes powerless deity than an omnipotent but unloving God (Pailin 1986:60). Finally, there can be found a miscellany of marginal solutions to the Problem of Evil, most 
of which either attempt to show that the three premises are not, after all, incompatible with each other because we should redefine or reinterpret concepts like God, omnipotence, omnibenevolence or evil (cf Pailin 1986:60-62).

Excluded here is the 'atheist' theodicy (if one can call it that) whose adherents insist that God's only excuse for evil is that he doesn't exist (cf Mackie 1982:1; Springfield 1968:73). For in atheist philosophy of religion the 'Problem of Evil' is inverted to become the so-called 'argument from evil' against the existence of God (cf Madden 1968:01; Mackie 1982:78-99).

What is somewhat perplexing, at least from the perspective of Old Testament Yahwism, is that not one of the attempted solutions to the Problem of Evil has bothered to consider the possibility that the divine might not be wholly or only benevolent. In what follows, I intend to play the devil's advocate by arguing for just such an unheard-of possibility based on the witness of monistic trajectories in biblical Yahwism. The aim will be to take a closer (if somewhat uncomfortable) look at what has been called the 'dark side' of YHWH and to assess the deity's role as the main antagonist when attempts at reconciliation between God and humanity, among humans themselves and between humans and their environment come to naught.

\section{RECONCILIATION AS PROBLEMATIC: YHWH AND EVIL IN THE OLD TESTAMENT ${ }^{2}$}

\subsection{Existence beyond reconciliation: YHWH and metaphysical evil}

Humans have since time immemorial had to reconcile themselves to the reality of metaphysical evil. Metaphysical evil can be defined as those fundamental and basic forms of negative states of being like death, contingency, entropy, disorder, negative change, transience, etc. In this regard, consider the following Old Testament texts, all of which many biblical scholars (contra Lindström 1983; cf also Levenson 1983) insist

2 Much of what follows here features an adaptation of a section in one of the chapters of my dissertation (cf. Gericke 2003). 
wittingly or unwittingly implicate $\mathrm{YHWH}$ in the actualisation of some forms of metaphysical evil:

Behold, it is I, and there is no other god apart from me; I kill and I make alive; I destroy and I heal, and there is no one who can save from my hand (Dt 32:39).

"I am YHWH, ... apart from me there is no other... I form the light and create the darkness; I actualise salvation and create evil. It is I, YHWH, who does all these things” (Is 45:5-7).

"Who speaks and causes it to happen? Did YHWH not command it? Does not both evil and good proceed from the mouth of the Most High?” (Lm 3:37-38).

"Behold, is it not from YHWH of hosts that people toil in fire and that the nations weary themselves for nothing?” (Hab 2:13).

In each of these texts, a monotheistic theology collapses into a monistic pan-causality. YHWH is the acknowledged source of metaphysical evil that encroaches perpetually on human existence. In other words, while YHWH is indeed the one who gives life, he is paradoxically also the one who kills. YHWH both create living beings and kills them off at an alarming rate. Thus the biblical character Naomi can without fear of being stoned for blasphemy tell the townspeople that it was $\mathrm{YHWH}$ himself who made her life bitter when he took everything that was precious to her (a husband and two sons) (cf Rt 1:20-21). Hanna can in the presence of the priest worship YHWH as the god who kills and makes alive (cf. $1 \mathrm{Sm} \mathrm{2:6).} \mathrm{Even} \mathrm{the} \mathrm{king} \mathrm{of} \mathrm{Israel} \mathrm{could} \mathrm{sincerely} \mathrm{ask:}$

“Am I God who kills and makes alive...?” (2 Ki 5:7).

It would therefore seem that the people of YHWH in ancient Israel and Judah did not believe that reconciliation with God or others would remove metaphysical evil. Death was a divinely ordained reality even before the first couple ate the forbidden fruit: hence the need to eat from the tree of life and the subsequent denial of access to it (cf $\mathrm{Gn} \mathrm{3}$; see also Barr 1992; contra Paul in Rm 5). Thus, blessings were to be had were for this life only, so that, even when the new heavens and new earth will be a reality, humans will still be mortal (cf Is 65:20). 
In the face of such an apparent dichotomy within the divine methodology of reconciliation, at least one biblical writer equated reconciliation with resignation:

- "Look at the work of God; who can straighten what he has made crooked?” (Ec 7:13).

- "Be happy on the good day; and on the day of evil, think as follows: Also this day God has made just like the other..." (Ec $7: 14)$.

For Qohelet, as for many other Old Testament authors, reconciliation was neither a recipe nor a right. In fact, when it comes to transience and entropy, some Old Testament texts seem to imply almost a nonchalant view of the matter on the part of the authors:

"You turn man to destruction and say, 'Return, sons of men'” (Ps 90:3).

"You hide your face and they are scared. You take away their breath and they die, they return to dust" (Ps 104:29).

"All flesh are like grass...the grass withers because the spirit of YHWH blows upon it” (Is 40:6-7).

Seen from this perspective, the point of reconciliation is a mystery. For it involves a deity who seems at times to be beyond good and evil; one in whom all metaphysical opposites were paradoxically reconciled (contra $\mathrm{Ml}$ 2:17).

\subsection{Reconciliation with the world: YHWH and natural evil}

According to many Old Testament texts, YHWH also has the power to control all natural phenomena, including meteorological, geologi-cal, and biological processes. In case of any dysfunction or mal-function in the operation of any of these systems, no one but the deity is implicated as being the ultimate necessary cause of the subsequent suffering (natural evil) that inevitably results.

Consider, if you will, the following examples of passages clearly implicating YHWH in the actualisation and maintenance of natural evil in the world. 
1) YHWH causes women's infertility:

"Then Jacob became angry with Rachel and asked, 'Am I in the position of God who has kept the fruit of the womb from you?'” (Gn 30:1-2)

“...YHWH had closed her womb” (1 Sm 1:6).

2) YHWH makes people disabled:

"And YHWH answered him, 'Who makes the mouth for the man, or who makes dumb or deaf and seeing or blind? Is it not me, YHWH?” (Ex 4:11).

3) YHWH even causes household plagues:

"YHWH spoke to Moses and Aaron saying, 'When you come to the land of Canaan which I give you as possession and I let leprosy come into a house...he whose house it is must go to the priest and say, "it looks as if there is a plague in my house'” (Ex 14:33-35).

4) YHWH is responsible for inhospitable weather:

"He throws ice in chunks; who is able to withstand the cold he sends?” (Ps 147:17).

5) YHWH is behind the cruelty in nature, including drought and crop failure, carnivorous activity, killing and pesti-lence:

“...if I stretch out my hand... and send a famine and destroy people and animals...If I let the wild animals roam the land so that they make it childless,... or if I bring the sword over the land...and I destroy man and beast in it...or if I send pestilence in that land and thus wipe out man and beast..." (Ezk 14:12-20).

"Before Him goes pestilence and in His wake follows the plague” (Hb 3:5).

From these texts, amongst many others, it should be clear that according to the underlying metaphysical ontology, YHWH is ultimately the necessary cause of all the natural evil in the world. Even though many a natural process sometimes appear to have an independent life of its own, whenever it wreaks havoc in human existence (e.g. as in the case of a locust plague) it is either because 
YHWH sent it (cf Ex 10) or due to the fact that he decided not to prevent it (cf $\mathrm{Ml}$ 3:17). Incidences like YHWH's (in?)famous orchestration of the ten plagues (Ex 6-11) leave no doubt that he is the Master of pest control and the Father of destructive meteorolo-gical and biological phenomena (cf. also Job 1-2; 38:22-36)

Of course, the reader should take cognisance of the fact that even in the Old Testament, the reason for human suffering in the face of cruel nature cannot in each case be traced back to some sin committed, which in turn caused the lamentable scenario. In this regard, many prayers in the Psalter (for example), ask YHWH to heal the supplicant - not in forgiveness of sins - but because it is YHWH himself who caused the illness (cf Pss. 22; 39; 69; 88; etc.).

That natural evil is divinely ordained part of YHWH's agenda for preventing complete reconciliation between man and his environment can particularly be seen in YHWH's creation of carnivores and omnivores. Animals (and humans) must kill and eat other animals for nutritional sustenance. This is by YHWH's express command to Noah (cf Gn 9). Yet even the writers of Old Testament texts did not consider this the ideal. In the Garden of Eden, humans only ate plants (cf Gn 2$3,9)$ and the author of trito-Isaiah could even long for a time when the lamb and the wolf would lie together and the lion would eat straw like an ox (cf Is 65:25).

Obviously, natural evil is perpetuated by the fact that YHWH also commanded humans to kill (euphemism: sacrifice) animals to achieve reconciliation. Animals must die when humans disobey the deity. Animals are even tortured on YHWH's command when humans fight each other:

"And YHWH said to Joshua: 'Do not fear for tomorrow this time I shall give them into your hand. You must cut off the hamstrings of the horses..." (Jos 10:6).

That the enemy's horses should be hamstrung thus causing them to suffer a slow torturous and agonising death simply smacks of sadism. For a deity who could give such a command, it should be clear that reconciliation with the natural world is therefore not always a live option. Moreover, with YHWH in control there remain some unanswered (and unanswerable?) mysteries, in connection with his 
relation to his creatures e.g.: Why does YHWH consider some of his own creations to be abominations (unclean animals) (cf Dt 14:3)? And why did YHWH endow humans with physiological processes which he himself seem to find offensive (menstruation, defecating, etc.) (cf Lv 15)?

The world, according to many Old Testament texts, is therefore obviously not the 'best of all possible words' as Leibniz's theodicy would have it. Moreover, though YHWH's profile as depicted in many an Old Testament texts does not fit the required qualifications laid down by philosophical theology when it comes to the attribute of omnipotence, YHWH is usually depicted as well enough in control of natural processes to have been able to prevent all natural evil if only he was also willing (cf Dt 28). Hence 'process theodicy' is also not applicable to the world in the text. And of course, both the free-will theodicy and that of 'soul-making' have never been able to account sufficiently for the amount of seemingly unnecessary natural evil in the world.

Ultimately, whether it be cruelty in nature, natural disasters or merely the usual natural processes which humans can at times find uncomfortable, cruel or horrifying, the Old Testament knows no other origin of natural evil than the divine mind itself. Thus the possibility that at times humans were able to reason with YHWH and to talk him out of his intended destruction of nature - even make him repent as if he was headed in the wrong direction and needed to be corrected - is an idea that frightens as much as it gives hope (cf Gn 18; Ex 32; Am 7)

\subsection{Reconciliation with other people: YHWH and moral evil}

Moral evil, in philosophy of religion, designates those types of evil that are committed by humans who, as a result of their actions, transgress the laws of God and/or society and, as a result, cause suffering to nature or other people (cf Hick 1990:103). Surely, in the quest for reconciliation between humans and God and between humans among themselves, the deity would not be both friend and enemy? Unfortunately, when it comes to the Old Testament and its varied depictions of YHWH, it is not difficult at all to find texts implying that, even with regard to this form of evil, no one but the deity himself is 
ultimately behind its actualisation, thus working not only for but curiously also against reconciliation:

1) YHWH determines the (evil) moral actions of people before they are born:

"And the angel of YHWH said to her, 'Behold, you are pregnant and will conceive a son and you must call him Ishmael because YHWH has heard you in your misery. And he shall be a wild ass of a man; his hand against everybody and everyone's hand against his. And he shall live against all his brothers'” (Gn 16:1112).

"And YHWH answered her, 'Two nations are in your womb and two peoples shall go out from your body. The one nation will be stronger than the other and the eldest will serve the youngest'” (Gn 25:22-23).

"In your book all my days were written, even before I was born" (Ps 139:16)

"YHWH has made everything for a purpose; yes, even the wicked for the day of evil” (Pr 16:4).

2) YHWH hardens people's hearts', which in turn causes them to sin so that reconciliation is prevented:

a) between humans:

"And I shall harden the heart of the Pharaoh...so that the Pharaoh will not listen to you" (Ex 7:2-3).

"But the king would not let us pass for YHWH hardened his spirit and made his heart obstinate" (Dt 2:30).

"For it was YHWH who hardened their hearts that they should come against Israel in battle" (Jos 11:20).

"He changed their hearts so that they would hate his people and act cunningly against them” (Ps 105:25).

b) between humans and God:

YHWH, why have you caused us to depart from your ways? Why do you harden our hearts so that we do not fear you? (Is 63:17a) 
c) and in general:

"The heart of man thinks about his way, but YHWH directs his footsteps" (Pr 16:9).

3) YHWH is even sometimes responsible when children disobey their parents:

"Is there not a woman among the children of Israel that you have to go to the uncircumcised heathen for a wife? But Samson's parents did not know that this was YHWH's way to look for an occasion against the Philistines" (Jdg 14:4).

"But they did not listen to their father because YHWH had decided to kill them" (1 Sam 2:25).

4) YHWH even corrupts the law system and is behind all cases of manslaughter:

"The earth is given over into the hands of the wicked, the faces of the judges he binds shut. Is it not he? Who else?" (Job 9:23-24).

"He who hits a person so that he dies must surely be killed. But if he did not intend it, but God made his hand meet it, then I shall show you a place to where he can flee" (Ex 21:13).

5) YHWH is even behind all political upheaval, be it justified or the violent, rebellious and chaotic actions of oppressing dictators and autocrats:

"The Most High rules the kingdoms of men and gives it to whomsoever he wills" (Dn 4:17; cf also 4:32; 5:21).

In these texts, it is clear that the moral evil involved would not have come about without the active role played by $\mathrm{YHWH}$ in its actualisation. This makes a mockery of the so-called 'free-will defence' to solve the Problem of Evil and justify YHWH's passiveness in the face of sin (contra Platinga 1974). For it should be clear from these texts that YHWH has no problem overriding the free will of people in actualising his inscrutable and sovereign agenda. YHWH's role in the actualisation of moral evil also destroys the idea that YHWH is interested in what is called 'soul making' or in creating 'the 
best of all possible worlds' (contra Hick 1968). If YHWH desired above all else only the reconciliation between him and people, and amongst the people themselves, he sure has a mysterious if not ineffective way of going about it.

But, rather than stop now that we have looked at all three forms of evil in the texts, let us consider a few additional materials that might reckoned as justification of the devil's advocate's unorthodox hypothesis

\subsection{Reconciliation and reward: Examples of YHWH comman- ding and/or rewarding evil acts}

Reconciliation between humans is not always YHWH's top priority. In fact, on several occasions, the Old Testament texts actually depict the deity as issuing commands to commit evil acts. In such instances, YHWH sees nothing indecent in having his own servants commit-ting evil/sin and enjoying the fruit of their criminal activities. Consider the following examples of such apparently unorthodox depictions of YHWH's role as instigator of - and co-conspirator in - his own people's morally questionable actions.

- "YHWH lets Abraham receive the Pharaoh's possessions after he deceived the king. Meanwhile, YHWH wants to punish the Pharaoh, knowing very well that he is innocent in the particular matter" (cf Gn 12:12-18).

- "YHWH allows the same thing to happen again, this time involving an innocent and even pious king Abimelech” (cf Gn 20:1-18).

- "YHWH asked Abraham to sacrifice his only son” (cf Gn 22:1-2).

- "YHWH tells the people to rob their Egyptian neighbours of all their prized possessions” (cf Ex 11:2-3).

- "YHWH tells the people to kill all the men-folk of the city and to take (literally 'rob') all the women and children and their possessions for themselves as spoils of war” (cf Dt 20:13-18).

- "YHWH tells Samuel to lie to Saul about the reason for his visit under the pretence of wanting to perform a sacrifice" (cf 1 Sm 16:1$3)$. 
- "YHWH claims to have given the people commands so that they would kill their children and defile themselves" (cf Ezk 20:20-27).

Thus with regard to Eutyphro's famous dilemma in the dialogues of Plato - whether what is 'good' is whatever the divine wills (thus implying that no act as such is necessarily evil) or whether the divine wills something because it is good (thus implying a higher order of reality to which even the divine must adhere) - elements of both ethical ontologies are present in the Old Testament. Here we have just seen that people do what God considers to be good even if in another context it might be considered evil (the first option in the dilemma). These examples of ethical ambiguity stand in direct opposition to other texts, e.g. Genesis 2-3, 18, etc. whether what is good is considered a standard independent of the divine (the second option).

Now in response to such embarrassing data, many Old Testa-ment scholars with a predisposition for apologetics would insist that the morality of ancient Israel is but a historically contingent pheno-menon projected wrongly onto what is really a loving God who did not really endorse the more repulsive elements of the morality represented in the texts (cf Eichrodt 1967:112). Of course, this is rationalisation and the essence of the dilemma for any view on the subject of reconciliation in the Old Testament is the embarrassing fact that YHWH's own beliefs about morality (as his beliefs about the world, history, etc.) never transcend the all-too-human ideas of his speechwriters (cf Gericke 2003:117-119).

From both a synchronic and a diachronic perspective, what YHWH views as right and wrong appears to vary between the various ideologies present in the pluralist theological ethics of the Hebrew Bible. This either means that YHWH does change his mind about what is right and wrong or, alternatively, that he does not and the authors were deluded. A third option is that there is no YHWH as depicted in the texts and the biblical character is just the projection and objectification of the will-to-power of the biblical authors' personal ideology (cf Gericke 2003:119). Whatever of these possibilities we opt for, thinking about reconciliation is no longer as simple as it once appeared to be. 


\subsection{Reconciliation and YHWH's inconsistent and passive approach to the proliferation of evil}

Old Testament scholars have taken notice of the fact that many Old Testament texts depict YHWH as sometimes frighteningly passive in the face of horrific evil (cf Crenshaw 1984:2; Brueggemann 1997:411). Several passages imply that YHWH is not sufficiently bothered by some atrocities and instead of taking an active and offensive approach to the matter prefers to passively let it happen and only afterwards react to the chaos (at best):

1) Contrary to the philanthropic witness of Deuteronomy and many a Psalm, Job insists that YHWH passively ignores the suffering of the poor and the helpless:

"Why does the Almighty not establish times of reckoning and do those who know him not see his days of judgement? They remove borderlines and steel herds of cattle...The ass of the orphan they drive away; the ox of the widow they take as a token. They push the needy off the road; the miserable ones in the land hide together. Look, like wild assess they...search for food...naked they spend the night...With no cover against the cold...the lack of shelter makes them press against the rocks. They pull the orphan from the breast and what the poor wears they sell. Naked they go without clothes; while they are hungry...they die of thirst. Out of the city, the men call and the souls of the wounded scream for help; yet God pays no attention to the injustice of it all” (Job 24:1-12).

2) At times, YHWH also seems to be passive in the face of unjust suffering despite his own covenantal obligations:

"You have pushed us away and made us a shame...our haters plunder as they please. You give us over like animals for the slaughter...you sell your people for nothing....all this have come over us even though we have not forgotten you or acted in betrayal of your covenant...awake, O YHWH, why do you sleep?” (Ps 44:10-24). 
3) In fact, YHWH can seem to be indifferently passive:

"It's the same for the righteous and the wicked; for the good and the bad; the clean and the unclean; for one who sacrifices and one who does not sacrifice. As it is with the virtuous, so with the sinners; the one who swears an oath and the one who is afraid to swear. This is the evil that is done under the sun: the same fate comes to all” (Ec 9:1-3).

4) YHWH's passivity thus causes perplexity:

"Just you are, YHWH, should I want to argue with you. Still, I want to speak with you concerning matters of law: Why is the way of the wicked prosperous? Why do they live in peace - all those who practice unfaithfulness. You have planted them and they take root; they grow and also do they carry fruit..." (Jr 12:1-2).

"When I think about it I become scared: why is it that the wicked grow old?" (Job 21:2; cf also Ps 73).

5) Qohelet could even level a veiled criticism of YHWH's passivereactive methodology:

"So I returned and considered all the oppressions that were done under the sun: and behold the tears of the oppressed and they had no one to comfort them; and there was power on the side of the oppressors; but there was no one to comfort them" (Ec 4:1-3).

"Because sentence against an evil work is not executed speedily, therefore the heart of the sons of man is set in them to do evil" (Ec 9:11).

Surely a candidate for the most pro-active paradigmatic event of reconciliation between $\mathrm{YHWH}$ and his people must be the liberation from Egypt. However, what is disconcerting is that YHWH passively watched the oppression for four hundred years before YHWH would act. Apparently he would not get involved before the sins of the people of Canaan had not reached the necessary quantity (another form of passivity in the face of evil) (cf Gn 15:13-15). Even worse, YHWH allegedly knew of this oppression since long before (as he told Abraham in Genesis 15) and it was he himself who ordained it. 
Ironically therefore, as Clines (1995:61) wryly observes, the author of Exodus who tells the story of YHWH's liberation of the people from Egypt forgot to mention that it was the same deity who liberated Israel from Egypt that made the people go down there in the first place (cf Gn 37-50).

Of course, the number of questions that one could ask YHWH with regard to his passive-reactive (if not provocative) agenda to the proliferation of evil (and based on expectations supplied by his orthodox profile) is infinite. Consider the following examples:

- "Why did YHWH put the trees in the (middle![of the]) garden if he did not want the couple to eat from it?” (cf Gn 3);

- "Why did YHWH create the snake and put it in the garden where it could deceive the couple?” (cf Gn 3:1);

- “Why did YHWH not prevent the murder of Abel?” (cf Gn 4);

- "Why did YHWH not prevent his 'sons' from having intercourse with women from earth?” (cf Gn 6);

- Why does YHWH not want humanity to be a global village with one language and near infinite potential (Gn 11)?; etc.

Why does YHWH so often denounce atrocities and heinous crimes after they have been committed instead of preventing them from occurring in the first place (cf e.g., Am 1-2; Ps 82 and passim)? After all, YHWH has no problem taking preventative measures in many less urgent situations (cf $\mathrm{Gn}$ 12, 16, 20 and passim). If $\mathrm{YHWH}$ can sometimes prevent evil, even when those plagued by it do not deserve it, he can do so always, if he really wanted. So why did he not intervene as before to prevent the raping of the concubine (Jdg 19); the rape of Tamar (2 Sm 13); the raping of Bathsheba and the murder of Uriah (2 Sm 11-12); the murder of Naboth (1 Ki 21); or any of a myriad other atrocities in the history of Israel and Judah? Why such an inconsistent and passive-reactive approach to evil instead of one that is consistent, proactive and offensive?

Contrary to popular belief, it is not a case of allowing evil in order to make room for the 'free will' of human agents in a relationship. After all, the Old Testament is full of tales depicting YHWH overriding people's will and intentions. In addition, the free-will theodicy fails in 
that it only considers the need for free will on the part of the agents committing the evil but blissfully ignores the fact that this is only possible at the cost of the free will of those that are victimised in the process.

The fact that so many atrocities (rape, murder, torture, starvation, violence, etc.) are committed in the world of the text without YHWH intervening speaks volumes for his relation to, and his role in, the actualisation of all sorts of evil and jeopardising the process of reconciliation. Such apparent indifference and inconsistency in dispensing retribution and justice cannot but leave the impression that YHWH either does not have immediate knowledge of suffering (cf Gn 18) or may know about the suffering, but just does not care enough to do anything (cf Job; Qohelet). But what is the point of reconciliation if it does not lead to protection from evil?

\subsection{Reconciliation and fair play: YHWH's indiscriminate and unfair punishment involving innocent parties}

In response to charging YHWH with evil, many apologists might still insist that God is completely fair and just and only allows evil to punish evildoers themselves. However, there are many texts in the Old Testament where YHWH goes about punishing not only evildoers but also innocent relations (e.g., descendents yet unborn) and bystanders (friends, family, acquaintances, company, etc.) who happen to be either related to the guilty party or unfortunate enough to be in the way of his divine wrath. Consider the following examples (to which many more could be added) in this regard:

"But now YHWH says ...In your house there will be no one who grows old throughout eternity...everyone who has remained in your house shall come before him (i.e. the priest) for a piece of money and a piece of bread. They shall say to him, 'Put me in one of the orders of priests that I may be able to eat a piece of bread"” (1 Sm 2:27-36).

"When David saw how the angel killed among the people, he spoke to YHWH and said, 'Look, $I$ have sinned and it was me who acted wrongly, but what have these sheep done?” (2 Sm 24:10-15).

"Therefore, the leprosy of Naaman will cleave to you and your descendants forever” (2 Ki 5:27). 
"Yes, even if they raise children, I shall make them childless...I shall kill the children of their wombs" (Hs $14: 12,16)$.

Look again at the text from 2 Samuel 24 above. What makes YHWH's action so irrational is not only the fact that others must suffer for David's actions (something which even David himself recognise to be morally retarded) but the fact that earlier in the same chapter we read that it was YHWH himself who incited the action for which he is now punishing David and his people. No wonder the author of Chronicles erased YHWH from the text and inserted 'the Satan' (cf 1 Chr 21).

Surely one of the most familiar examples of YHWH implicating innocents for the sins of others occurred when he doomed all descendants of Adam and Eve to a lifetime of suffering and misery. YHWH could simply have punished the couple themselves or gave them a second chance (as he did when David sinned with rape and murder). Instead, for eating forbidden fruit (which YHWH could have placed out of their reach if he wanted to), people not yet born and nature in its entirety were cursed to live a life a hardship and suffering (cf Gn 3:16vv).

Of course, need it be said that it is quite irrelevant that some Old Testament texts (e.g. Dt 24 and Ezk 12) deny that YHWH punishes innocents such as descendants and other relations. These texts, along with David's question to YHWH in 2 Samuel 24, merely witness to biblical ideological pluralism. It also implies that even ancient Near Eastern people with their ideas of corporal solidarity could realise the absurdity of collective and trans-generational retribution. Yet such recognitions are the exceptions to the rule. The tendency of YHWH is to hold bystanders and descendents accountable for the sins of others (cf also Jos 7; $2 \mathrm{Sm} \mathrm{21).} \mathrm{And} \mathrm{if} \mathrm{this} \mathrm{is} \mathrm{the} \mathrm{case,} \mathrm{what} \mathrm{are} \mathrm{the}$ implications for a biblical theology of reconciliation?

\subsection{Reconciliation with whom? YHWH's co-operation with the forces of evil}

In some attempts to prevent reconciliation, YHWH does not work alone. Many Old Testament texts depict YHWH as a co-conspirator with the forces of evil. 
"When Abimelech had ruled for three years over Israel, God sent an evil spirit between Abimelech and the children of and the people of Shechem” (Jdg 9: 22).

"But the spirit of YHWH had departed from Saul and an evil spirit sent by YHWH frightened him. Then the servants of Saul said to him, 'Look, an evil spirit from God frightens you” (1 Sm 16:14-16).

"I have seen YHWH sitting on his throne while all the hosts of heaven stood next to him...And YHWH said, 'Who will convince Ahab so that he can go up and fall at Ramoth in Gilead'? And the one said this and the other one that. Then the spirit came forward and went to stand before the face of YHWH and said, 'I shall convince him'. And YHWH asked him, 'With what'? And he said, 'I shall go out and become a lying spirit in the mouth of all his prophets'. And YHWH said, 'You will convince (him), yes, you will win (him) over, go out and do so! And now, look, YHWH gave a lying spirit in the mouth of all these prophets and YHWH spoke evil against you'” (1 Ki 22:19-23).

As Carroll (1991:54) notes, some sophisticated apologist might want to distinguish between committing evil and commanding others to do so. Whatever the case may be, the fact remains that if the authors of evil cannot do so without YHWH's consent he is technically the necessary cause of the particular evil. For without his sanctioning of demonic activity there would be no demonic destruction. YHWH's compliance with the forces of darkness, in a context where they can do nothing without his consent, therefore seems to implicate him in their activities.

That YHWH is ultimately to blame even for the havoc caused by evil spirits is particularly clearly implied in the story of Job. For though it is Satan who actually afflicts Job, it is only by YHWH's consent to do so (cf Job 1-2). Moreover, after the first series of tragedy's the Satan caused, YHWH admits that it was he himself who destroyed Job for no good reason (cf Job 2:3). And after the whole sorry business, when Job is comforted with a set of replacement children, it is explicitly said that his friends came to console him for the evil $Y H W H$ had done to him (cf Job 42:11).

This seemingly unorthodox tendency of implicating YHWH in the actualisation of evil when it is humans or other divine beings who 
actually commit the foul deeds is particularly visible in the Old Testament's apocalyptic literature. In the book of Daniel, whenever the predictions tell of a malignant force committing great atrocities, it is euphemistically asserted that the power to blaspheme against heaven and destroy what is holy and precious 'was given to him'. This passive form of expression without explicit reference to the divine prompts the question: 'Who gave the power'? and implies the answer 'Who else'? (cf Dn 8-11). Of course, the proper response to such a scenario of might-makes-right is to bow before YHWH's absolute power because:

“...none can stay his hand or say unto him, 'What are you doing?'” (Dn 4:15)

Once it is alleged that $\mathrm{YHWH}$ is the sovereign creator and manager of everything that exists, the deity will always ultimately remain responsible for the evil the malignant forces commit since they can do nothing without his consent. Thus ironically, the attempt of the authors of apocalyptic text are able to encourage pessimism and despair even as they set out to assure their readers that there is reason for hope. As for reconciliation, what does one expect from a deity who gives the following all-too-considerate (to the demonic) command to Israel with regard to procedures on the annual 'Day of Atonement (read 'reconciliation'):

"And Aaron shall cast lots upon the two goats; one lot for YHWH and one lot for Azazel” (Lv 16:8).

So unless one opts for dualism or polytheism, the concept of absolute monotheism, coupled with a doctrine of omnibenevolence and the reality of evil in the world, always deconstructs itself and collapses into monism. And when YHWH is not directly implicated in an evil committed, he has others to do the dirty work and share the spoils. This makes reconciliation a complex matter indeed.

\subsection{Weird reconciliation: YHWH's methodology of causing evil to punish evil}

On numerous occasions in the Old Testament texts, YHWH raises up enemies for his people in order to punish them. Thus he and his people can be reconciled. However, these enemies he raises, all of whom are clearly themselves surely in need of reconciliation with both the divine 
and Israel, are caused to kill, torture, starve, rape, rob and destroy everything in sight:

"YHWH will bring against you a nation from afar... a nation hard of face who does not pardon an old man and shows no mercy to a boy...and you will eat the fruit of your body, the flesh of your sons and daughters whom YHWH has given you...” (Dt 28:49-53).

"Then YHWH sent the gangs of the Chaldeans against him and the gangs of the Arameans and the gangs of the Moabites and the gangs of the children of Ammon. He sent them against Judah in order to destroy it according to the word of YHWH that he spoke through the service of his servants, the prophets" (2 Ki 24:2).

"Samaria will pay for her rebellion against God; they shall fall by the sword; their children will be dashed and their pregnant woman will be cut open” (Hs 14:1).

"For I shall gather the nations to fight war against Jerusalem; and the city will be taken, the houses plundered and the women raped..." (Zch 14:2).

YHWH could have caused those he wished to punish to die from a heart attack, to suffer a stroke, to be struck by lightning or to fall into a crack in the earth (cf Jos 7; Nm 16; 1 Sm 25; etc.). Instead, before reconciliation is possible, YHWH wants to punish people in a most violent and explicit manner by causing other yet uninvolved people to commit horrible atrocities. These agents of divine retribution are made to commit murder, rape, torture and other evil acts so that YHWH's vengeance can be enacted and his wrath sated.

In punishing evil by causing more of the same (and creating the need for yet more retribution) YHWH initiates a seemingly endless cycle of obscene, abhorrent and unjust tit for tat. Moreover, puppets of retribution committing the evil has no free will, since they must fulfil YHWH's predictions from a time before they were born. And to top it all, after YHWH have stirred people to commit evil against his people, he holds his puppets accountable for the deeds he himself made them commit (cf Is 11; Jr passim)! In other words, reconciliation between YHWH and Israel came at a price: the prevention of reconciliation between $\mathrm{YHWH}$ and the nations and between the nations amongst themselves. 


\subsection{The dark side of reconciliation: divine deception}

Some scholars not constrained by dogma have made an effort to point out that, within the Old Testament texts, one sometimes encounters scenarios where YHWH is depicted as being involved in the deception of people (cf Carroll 1979:212-216). The following examples, amongst others, should suffice as yet a few more witnesses to the so-called dark side of YHWH:

"But YHWH has determined to confuse the counsel of Achitophel so that YHWH could bring evil on Abshalom” (2 Sm 17:14).

“...YHWH, you have greatly deceived this people and Jerusalem saying, 'You shall have peace; whereas the sword reaches our souls'” (Jr 4:10).

"And, if the prophet lets himself be deceived to speak, it is I, YHWH, who deceived the prophet..." (Ezk 14:9).

As Carroll (1979:157) noted, the possibility of divine deception is a taken for granted element of Old Testament theology and was the only recourse when prophecy failed. However, this dark side of the divine is not orthodox and needs to be repressed and reinterpreted by those who consider themselves to be biblical theists. For if the divine deceives people one can never be sure of what to believe or what to do. Thus, on some occasions in the biblical stories, YHWH seems to act quite contrary to what they would expect from him given the veracity of earlier revelation (cf Clines 1980:37). There are several instances in the text where it becomes clear the first impressions can be deceptive, e.g.:

- "YHWH gives Moses a mission to complete then attacks him on his way to complete it" (cf Ex 4:23-26).

- "YHWH allegedly abhors idolatry and therefore the beliefs of pagan nations yet he himself limited his revelation to Israel and gave the sun, moon and stars for the other nations to worship" (cf Dt 4:19).

- "YHWH tells the people to prepare for war only to twice lead them into being slaughtered (with a total of forty thousand casualties” (cf Jdg 20).

- 'YHWH allows a 'man of God' to be fatally deceived when he 
sincerely intended to act only in obedience to the divine word" (cf 1 Kgs 13).

- "God gives some people riches but then capriciously prevents him from enjoying it” (cf the 'grievous evil': Ec 6:1-2).

As Crenshaw (1984:11) notes, however one may wish to explain or justify these bizarre acts of the biblical god, the fact remains that they deconstruct the attribute of divine omnibenevolence as it is understood in orthodox dogmatic theology and philosophy of religion and seriously complicates any optimistic theory of reconciliation.

If above all else YHWH was interested in reconciliation, what would be the rationale for deception? Does this not put a break on the whole operation of reconciliation making it into a façade and a farce? (cf also Davidson 1992:102). Are there not other ways of foiling the plans of evildoers than for YHWH to become a deceiver himself? Can a deity with a propensity for deception be trusted? Or does even the thought of the possibility of divine deception drive one mad in the way Descartes thought would be the case if his thinking were not to be trusted (cf. also Dt 13). In this case, is reconciliation even a desireable prospect?

\subsection{Reconciliation and love: some bizarre acts of YHWH}

In light of all that has thus far being said regarding YHWH's role in the actualisation of evil, it would seem that when the Old Testament speaks of YHWH's 'love' for people or their 'love' for YHWH; it appears to involve something very different from the love most people envisage. Reading through the biblical narratives it is clear that people like Abraham, Jacob, Moses, David, Jeremiah, Job, Elijah and others did not actually love YHWH in the sense we use the word. To be sure, they 'feared' YHWH and were very loyal (attached), but when they spoke of his mercy, kindness and loyalty, it is not words of intimacy but the cowering of an impotent subject before an implacable ruler with absolute power. In contrast, when we think of 'love' we think of tenderness, compassion, care and respect. The last thing we have in mind is YHWH telling Jeremiah:

Arise and speak to the people all that I tell you. Do not be afraid of them or I shall destroy you before their eyes (Jr 1:17). 
Such excessiveness of 'tough love' permeates the entire Old Testament. For example, when Job finally gets an audience with YHWH, the deity responds with a condescending answer that is not so much a loving response as an evasion and a humiliation of Job who, so it is implied, should be silent like the puny audacious, inquisitive and impotent mortal that he is (cf Job 38-41). In 2 Samuel 6 we read that the same caring and compassionate god wasted Uzzah, not for doing something obscenely evil, but merely because the pious man saw that the ox-cart was wavering and therefore wanted to steady the Ark of God on it so it wouldn't fall off. And surely, 'love' cannot possibly be the most apt word one might use in describing the disposition of a deity who sends two bears two maul forty-two small children simply because they teased the prophet Elisha about his baldness.

It is therefore no surprise that some of YHWH's most loyal subjects, people like Moses, Elisha, Jeremiah and Job had one ominous thing in common: they all reached a point where they accused YHWH of being unreasonable and either insisted that if he really cared about them he must do them a favour and end their lives, or they gave vent to their frustrations by throwing a tantrum and cursing their birthdays (cf Ex 32; Jr 15; 20; 1 Ki 19; Job 3; etc.).

Of course, there is no need to deny that there are numerous texts that seem to insist, when read in isolation, that YHWH is nothing but a loving god who has nothing whatsoever to do with any sort of evil. But when one no longer represses those uncomfortable contrary texts that stand juxtaposed to such user-friendly material and dare to take a long hard look at the kind of evil YHWH is often depicted as doing in the lives of people (or the good he neglects to do, though he does it elsewhere) words about YHWH's deeds of 'loving-kindness' seem hollow. Even much that goes under the name of worship might yet amount to no more than the empty words of Job's orthodox and pious friends. Though they were the ones that defended God's honour in the face of Job's blasphemy, in the end it is they and not Job YHWH reprimands for having spoken wrongly of him (not about Job; cf Job 42:7). It was they, and not Job, who were most in need of reconciliation. 


\section{RECONCILIATION AND EVIL: OLD TESTAMENT VS NEW TESTAMENT}

It should be remembered that even before the time of Marcion, even within the Old Testament itself, the monism prevalent in some trajectories of pre-exilic Yahwism became unacceptable for many of the faithful. Thus we find the development of a complex demonology in late Second Temple Judaism and, especially in the inter-Testamentary literature, a rewriting of earlier texts to absolve YHWH from the charge of being the ultimate source of evil.

In this regard, it is well known that one of the enduring problems in biblical theology is the relation between the Old and New Testaments. On a variety of issues, continuity and discontinuity abound. When we consider the level of theology (i.e. God-talk), one popular stereotype claims that the God of the Old Testament is cruel, but that the God of the New Testament is kind and compassionate. And while this is indeed a hopeless generalisation, it must be said that the idea is not without some justification.

However, notwithstanding such a concession, it is typical for scholars concerned with refuting such a view to construct a positive apologetic by insisting that not only is the God of the Old Testament and the God of the New Testament one and the same being (as the New Testament authors indeed imply) but the God of the Old Testament is just as loving. In fact, most of the New Testament views on divine love have as precedent confessions to be found in Old Testament texts such as Deuteronomy, the Psalms, Jeremiah, Hosea, etc.

Now while such a way of creating a more balanced view of the relation between the Testaments as far as the divine nature is concerned is certainly laudable, what would happen if one tried to deconstruct the stereotype with a negative apologetic? In other words, instead of showing that the God of the Old Testament can be just as loving, how about showing that the God of the New Testament can be as implicated in the actualisation of evil as YHWH is? For consider the following examples of witnesses in the texts that appear to create a continuity with Old Testament monism and pan-causality:

According to Matthew's Jesus, not even a swallow falls to the ground without God. Whether this means 'without the will of God' so 
that God is implicated as the direct cause or whether it merely means 'God is present', and therefore passive and negligent in the face of natural evil, is irrelevant (cf Mt 10:29).

In the Lukan version of the temptation of Christ, the Satan says that all the kingdoms of the world were given to him and that he gives it to whom he pleases (cf Lk 4:6) Given by whom? In Luke's version of Jesus' justification of his use of parables in teaching, the motivation for talking in such an obscure fashion is said to be precisely so that the people will not understand and repent! (cf Lk 8:10).

The Johanine Jesus says in 12:40 that the people did not believe in him because God dulled their senses in order that they should not repent and be healed (Just like YHWH told Isaiah).

In his speech on Pentecost Peter tells the Jews that Jesus was handed over to them to be crucified by the counsel and foreknowledge of God. This means that God had to make sure that the people would kill the Messiah, for if they accepted him, he would not have died for their sins (cf Ac 2:23).

According to Paul in Romans 1-5, all the people of the earth who were yet unborn when the first couple sinned are subsequently guilty and being punished for that crime in that they must die. As in the Old Testament, this implies the reality of trans-generational culpability.

In Romans 9:10-23 Paul insists that God is ultimately the one who hardens people's hearts and who causes them not repent. In response to a hypothetical objection to such a view by his readers he simply insists that the potter may do with the clay as he wish and that humans are in no position to criticise God even if he makes some people evil only to be able to show off his wrath.

According to Thessalonians 2:11, it is none other than God who sends delusion so that people who have acted wicked will believe the lies of demons.

In the Book of Revelation, all the natural evil that occurs in the world is the result of the ordinations and commands of God (cf Rv 5ff). The demonic beasts and the devil who deceive the people of the world and kill the faithful only have the power to do so because it 'was given to them' (by whom?) (cf Rv 12-20). Revelation 17:17 insists unabashedly that the forces of evil do what they do because God 
himself configured their thoughts to act in that particular manner. According to Revelation 22:11, those who are evil should not only stay evil but become even more so!

One could go on and on and on. Upon closer scrutiny, even the New Testament authors could not completely sever the link between God and evil and rid themselves wholly of depicting the divine with a dark side. Of course, one does not need to deny that there are many beautiful texts depicting God as the only source of what is good. But as in the Old Testament, such confessions and stories are juxtaposed with incidental comments, characterisations and assertions implying that paradoxically, this same God is in some way also ultimately the one in control of metaphysical, moral and natural evil in the world.

\section{OLD TESTAMENT MONISM, RECONCILIATION AND EVIL TODAY}

Does anybody today believe in YHWH? Does anyone still subscribe to the Old Testament views on the relation between YHWH and evil? Can you say that you believe in the God of the Bible but refuse to admit that he is inextricably involved with the evil in the world as the majority of the biblical witnesses imply? For if people believed in YHWH they would also adhere to a deuteronomistic philosophy of history (not unlike what is still found in Islam) and would have no problem to believe that things like war, tsunamis, the Holocaust, Hiroshima and Nagasaki, Apartheid, Communism, the Israeli-Palestinian conflict, international terrorism (9/11), contemporary poverty and violent crime in South Africa, droughts, famine, AIDS, political oppression, personal misfortune, etc. are all acts of God.

Such a seemingly primitive and outrageous hermeneutic of contemporary reality is nothing if not biblical. It is therefore curious that many theologians and preachers who insist that the Bible tells us what God is really like go out of their way to insist that to believe things like these is not only wrong and unbiblical [sic], it is also supposedly based on an outdated view of a God who intervenes directly in human affairs and who is as evil as he is loving. They view monism as but one (allegedly redundant) trajectory in the biblical witness that they may choose to ignore whilst focussing selectively on more userfriendly and comforting sentiments. Science, so they tell us, has made 
such a link between YHWH and history (as in deuteronomistic theology) and between YHWH and natural disasters (interventionism) inconceivable. Of course, this assertion implies that YHWH as depicted in most of the Old Testament texts is but a character of fiction.

It seems that people today no longer believe in YHWH - the living God - but in 'The Lord', a pseudo-biblical entity (an ideal idol?) who (so they say) is never responsible for evil and who otherwise conforms conveniently in terms of profile to the stipulations laid down by currently vogue ideas in dogmatic and philosophical theology. For if people did believe in YHWH, they would not wonder whether God existed when tragedies occur but would instead join Eli in the stoic confession that no matter what happens: 'It is YHWH' (1 Sm 3:18; cf 1 Sm 2:6).

Then question then is whether people actually want to be reconciled with YHWH as he is depicted in the biblical texts. For just about every biblical theist - be they conservative, liberal or radical in their theology - continue to insist both that the Bible is the foundational document for their faith and that the God they believe in is perfectly loving and not behind the evil in the world. How these people reconcile their texts with their theology therefore seems to involve a generous dose of repression. To claim that one believes that the biblical God exists and that God is only benign and never malignant is only possible if one engages in systematic theology in ignorance of biblical theology. It is a case of doing philosophy of religion whilst bracketing the history of religion.

\section{CONCLUSION}

Any biblical theology of reconciliation seems problematic when considered from the perspective of some of the Old Testament's views on the relation between YHWH and evil. For very few people today can bring themselves to join Job in confessing that:

"YHWH gives and YHWH takes away...” (Job 1:21);

"Shall we accept only the good from the hand of God and not the evil?” (Job 2:10).

Monistic sentiments like these are virtually unheard-of when theologians write about reconciliation or ponder the Problem of Evil. 
Of course, taking seriously the monistic traditions in the Old Testament will complicate any optimistic theology of reconciliation immensely. It will also deconstruct the 'Problem of Evil' and just about every popular theodicy currently in circulation. And how could it be otherwise when YHWH seems to be depicted as being almost beyond good and evil? What should we make of a divine agenda that seems to be concerned with something beyond reconciliation?

\section{Consulted literature}

Archer, G L 1982. Encyclopaedia of Bible Difficulties. Grand Rapids: Zondervan Publishing House.

Barr, J 1984. Escaping from Fundamentalism. London: SCM Press.

-, 1992. The Garden of Eden and the Hope of Immortality. London: SCM Press.

-, 1998. "Was Everything God Created Really Good? A Question on the First Verse of the Bible.” in Linafelt, T and Beal, T K (eds), 1998. God in the Fray: A Tribute to Walter Brueggemann. Minneapolis: Fortress Press.

Brueggemann, W 1997. Theology of the Old Testament. Minneapolis: Fortress Press.

Carroll, R P 1979. When Prophecy Failed. London: SCM Press.

-, 1991. Wolf in the Sheepfold: The Bible as Problem for Christianity. London: SCM Press.

Clines, D J A 1980. "Yahweh and the God of Christian Theology". Theology 83, 323-330.

-, 1995. Interested Parties: The Ideology of Readers and Writers of the Hebrew Bible. Sheffield: Sheffield Academic Press, Ltd.

Crenshaw, J L (ed.) 1983. Theodicy in the Old Testament. IRT 4. Philadelphia: Fortress Press.

-, 1984. A Whirlpool of Torment: Israelite Traditions of God as an Oppressive Presence. Minneapolis: Fortress Press.

Davidson, R 1992. The Courage to Doubt. London: SCM Press.

Gericke, J W 2003 Does YHWH exist? A philosophical-critical reconstruction of the case against realism in Old Testament theology. (Unpublished PhD Thesis). Pretoria: University of Pretoria.

Hick, J 1968 Evil and the God of Love. London: Fontana

-, 1990 Philosophy of religion ( $4^{\text {th }}$ rev ed.) New Jersey: Prentice Hall Inc. 
Levenson, J D 1988. Creation and the Persistence of Evil: The Jewish Drama of Divine Omnipotence. San Francisco: Harper \& Row

Linafelt, $\mathrm{T}$ and Beal, $\mathrm{T} \mathrm{K}$ 1998. God in the Fray: A Tribute to Walter Brueggemann. Minneapolis: Fortress Press.

Lindström, F 1983. God and the Origin of Evil: A Contextual Analysis of Alleged Monistic Evidence in the Old Testament. Lund: CWK Gleerup.

Mackie, J L 1982. The Miracle of Theism: Arguments For and Against the Existence of God. Oxford: Claredon Press.

Pailin, D 1986. Groundwork of Philosophy of Religion. London: Epworth Press.

Platinga, A 1974. God, Freedom and Evil. New York: Harper and Row.

Smith, G 1979. Atheism: The Case Against God. New York: Prometheus Books.

Springfield, I L 1968. Evil and the Concept of God. London: Charles C Thomas. 